\title{
THE ROOT OF UNION WITH CHRIST: COMPARISON OF ELECTION IN JOHN CALVIN AND KARL BARTH
}

\begin{abstract}
Jason Zhao
STT Reformed Injili International (Mandarin)

Korespondensi: jason.ires@gmail.com

Diajukan: 16-Sept-2017; Direview: 26-Sep-2017; Diterima: 12-Okt-2017; Direvisi: 19-Okt-2017

ABSTRACT: As two of the arguably greatest theologians in church history, both John Calvin and Karl Barth have recognized the significant role of union with Christ and presented it in their works respectively. However, there is no study devoted specifically on the comparison of the two theologians' thoughts regarding this critical theme. This article will start from exploring Calvin and Barth's doctrine of election, the root of their theology of union with Christ. Karl Barth frankly admits that he has departed from Calvin radically on the doctrine of election. While vindicating Barth's assertion, this article further argues that Calvin and Barth's divergent understandings on the root of union with Christ are driven by their contrasting ontological presuppositions. The clarification of that rooted difference will pave the way for our future study of Calvin and Barth's distinctive characterizing of union with Christ.
\end{abstract}

KEYWORDS: John Calvin; Karl Barth; the Root of Union with Christ; Election; Ontological presupposition.

ABSTRAK: Sebagai dua teolog raksasa di dalam sejarah gereja, baik John Calvin dan Karl Barth telah mengenal peran yang penting akan kesatuan dengan Kristus dan mempresentasikannya di dalam karya mereka masing-masing. Akan tetapi, belum ada studi yang dikhususkan untuk memperbandingkan kedua pemikiran teolog ini mengenai tema yang kritikal ini. Artikel ini memulai dengan menjelajahi doktrin pemilihan Calvin dan Barth, akar dari teologi mereka mengenai kesatuan 
dengan Kristus. Karl Barth secara jujur mengakui bahwa dia telah berpisah dengan Calvin di dalam doktrin pemilihan secara radikal. Dengan menyetujui yang Barth ungkapkan, artikel ini berargumen lebih lagi bahwa pengertian Calvin dan Barth yang bercabang mengenai akar dari kesatuan dengan Kristus karena disebabkan oleh presuposisi ontologis mereka yang kontras. Pencerahan akan akar perbedaan ini akan melapangkan jalan untuk studi kita selanjutnya mengenai pemahaman Calvin dan Barth yang unik dalam mengkarakterkan Kesatuan dengan Kristus.

KATA KUNCI: John Calvin; Karl Barth; Akar Kesatuan dengan Kristus; Pemilihan; Presuposisi Ontologis.

\section{Introduction}

The doctrine of union with Christ per se has gone through heated debate for decades, both in its ontological and soteriological aspects. As D.A Carson observes, at the heart of debate over several important theological issues today, union with Christ stands as the unifying theme which is in need of explication and clarification. ${ }^{1}$ This paper aims to benefit the body of Christ by further clarifying the wonderful truth of unio mystica cum Christo given by God.

As two of the arguably greatest theologians in church history, both John Calvin and Karl Barth have recognized the significant role of union with Christ and presented it in their works respectively. However, there is no study devoted specifically on the comparison of the two theologians' thoughts regarding this critical theme. Therefore, this paper, through a comparative investigation, will explore the parallels and distinctions between Calvin and Barth's theology of union with Christ. ${ }^{2}$ In this article, I will firstly exposit their distinct ontological

\footnotetext{
1 Constantine R. Campbell, Paul and Union with Christ: An Exegetical and Theological Study (Grand Rapids: Zondervan, 2012), preface.

2 The primary resources for this study are Calvin's Institutes of the Christian Religion and Barth's Church Dogmatics, and their commentaries or other writings shall be discussed only as it pertains to the themes and topics discussed herein.
} 
presupposition and the root of their doctrine of union with Christ. After laying the foundation, Calvin and Barth's doctrine of union with Christ per se will be analyzed attentively in another succeeding article.

\section{Comparing Calvin and Barth?}

Before carrying on the study, we must first answer the questioning raised by Richard Muller, the prominent Calvin scholar, who is very negative at the comparison between Calvin and Barth:

There must, in other words, be a comparative element in any discussion of Calvin's thought, but it must not be a broad and generalized comparisonmuch less an eclectic one!-set by the agenda of the modern author. Projects that compare Calvin and Barth or of Calvin and Schleiermacher will not enlighten us particularly about Calvin-nor probably about Barth or Schleiermacher, for that matter. ${ }^{3}$

Muller's aim here is to avoid any "modern Barthian or Schleiermacherians" distortion of Calvin, which forces Calvin to "fit neatly into the dogmatic, existential, or psychological paradigms" of twentieth-century scholarship. ${ }^{4}$ But it seems that he also shuts the door for any comparison between Calvin and Barth, which becomes a burden for later scholars.

Van Der Kooi, in his book As in a mirror, agrees with Muller that "Calvin and Barth were both connected with their contemporaries within a fine-meshed existing concepts and forms of exegesis," yet he argues for the possibility of a fruitful comparison. ${ }^{5}$ To keep the balance, Van Der Kooi adopts an indirect approach, in which he introduces Immanuel Kant as the transitional figure to "describe the changed constellation of theology after Kant." 6 David Gibson, when comparing Calvin and Barth,

\footnotetext{
3 Richard A. Muller, The Unaccommodated Calvin: Studies in the Foundation of a Theological Tradition (Oxford University Press, 2000), 187.

4 Ibid., 14.

5 Cornelis van der Kooi, As in a Mirror: John Calvin and Karl Barth On Knowing God: a Diptych (Leiden: Brill, 2005), 4.

$6 \quad$ Ibid., 5.
} 
also appreciates Muller's emphasis of contextual complexities. ${ }^{7}$ However, he refutes the view of bracketing both theologians off "from each other completely in the interest of faithful interpretation," which, according to Gibson, "is to exaggerate the need for methodological care." 8 Moreover, Gibson points out that Muller's important conception of the Christological distinctions between Calvin and Barth is derived through the comparative method as well. ${ }^{9}$ Above all, to maintain faithful interpretation of the two theologians by rejecting the direct comparison is like to throw out the baby with the bathwater. Thus, this paper will be in line with Gibson's argument on comparing Calvin and Barth while fully perceiving the contextual complexities.

\section{The Ontological Presupposition of Union with Christ}

\section{Calvin}

John Calvin's close theological relationship with the church fathers and medieval doctors decides that it is impossible to interpret Calvin, the humanist, accurately without understanding the later medieval scholasticism. ${ }^{10}$

After Thomas Aquinas's modification of Aristotle's thought, the Christianized Aristotelian view of nature and world became the dominant force until $17^{\text {th }}$ century in Europe. ${ }^{11}$ Undoubtedly, there are continuities and discontinuities between the Reformation and the scholasticism. Simply picturing the Reformation as a battle of the early "Platonic/ Augustinian model" against the "Aristotelian/ Aquinas model" could be very misleading. ${ }^{12}$ In spite of Luther and Calvin's overtly

\footnotetext{
7 David Gibson, Reading the Decree: Exegesis, Election and Christology in Calvin and Barth (London: T \& T Clark, 2009), 17.

8 Ibid.

9 Ibid.

10 See A N S. Lane, John Calvin: Student of the Church Fathers (Edinburgh: T \& T Clark, 1999).

11 Richard A. Muller, Post-Reformation Reformed Dogmatics: The Rise and Development of Reformed Orthodoxy, Ca. 1520 to Ca. 1725, 2nd ed. (Grand Rapids: Baker Academics, 2003), vol.1, 372-373.

12 Richard A. Muller, "Scholasticism, Reformation, Orthodoxy and the Persistence of
} 
polemics against scholastic theology, Richard Muller argues that the Reformation "is the briefer phenomenon, enclosed as it were by the fivehundred-year history of scholasticism and Christian Aristotelianism." 13 Neither Luther nor Calvin, says Muller, "ceased to view the world as ordered according to the fourfold causality or as fitting into a universe of concentric spheres, each of which was moved by an angelic mover."14 Thus, it is reasonable to conclude that the modified Christian Aristotelianism should be an important conceptual tool when Calvin constructs his theology.

Ontologically speaking, the "modified Christian Aristotelianism" means that, on the one hand, Calvin rejects philosophical or metaphysical speculation by subordinating reason to the Scripture, and shows more interest with God's act than "his incomprehensible essence"; 15 on the other hand, he retains the essentialism view of divine ontology by affirming God's aseity with "eternity" and "self-existence" and characterizing God as "kindness, goodness, mercy, justice, judgment, and truth."16 In the traditional Aristotelian categorization, ousia (substance or essence) is the most fundamental element for every being, which defines what a particular thing is. Calvin, from time to time, points out that the essence of God is "incomprehensible, infinite and spiritual" towards His creatures. ${ }^{17}$ That is to say (though paradoxically), in terms of the content of God's revelation toward human, the fundamental and first fact, for Calvin, is God's hiddenness and His immeasurable and incomprehensible majesty, which ought to trigger man's awe and worship immediately. The later Calvinist Herman Bavinck succinctly summarizes that "Mystery is

\footnotetext{
Christian Aristotelianism," Trinity Journal, NS 19/1 (1998), 82.

13 Muller, Post-Reformation Reformed Dogmatics, vol.1, 39.

14 Richard A. Muller, "Reformation, Orthodoxy, 'Christian Aristotelianism,' and the Eclecticism of Early Modern Philosophy," Nederlands Archief voor Kerkgeschiedenis 81 (2001), 306.

15 Calvin, Institutes I.11.3. See also Van der Kooi, As in a Mirror, 121-124.

16 Calvin, Institutes I.10.2.

17 Calvin, Institutes I.13.1.
} 
the lifeblood of dogmatics." 18

Nevertheless, neither Calvin nor Bavinck negates the possibility of knowing God. While trying to prevent any speculation about God through the incomprehensible essence, Calvin does not deny but instead limits the knowledge of God to God's self-revelation in His voluntary condescending works:

Consequently, we know the most perfect way of seeking God, and the most suitable order, is not for us to attempt with bold curiosity to penetrate to the investigation of his essence, which we ought more to adore than meticulously to search out, but for us to contemplate him in his works whereby he renders himself near and familiar to us, and in some manner, communicates himself. ${ }^{19}$

Instead of men ascending to God, Calvin's emphasis is on the descent of God towards men, in which God "must descend far beneath his loftiness." ${ }^{20}$ The self-revelation of God, whether in creation, in Scripture, in Jesus Christ or in the Sacraments, always bears the feature of accommodation. Because the fundamental distance between God and humans, Creator and creature, must be bridged by God accommodating Himself to man's feeble capacity, especially after the fall. Van der Kooi even considers the concept of accommodation as "a central element in Calvin's theological epistemology."21

During the Reformation period, not everyone shares the same view of divine ontology and revelation as Calvin, but this theocentric metaphysical context was the root for all knowledge at that time.22 It was a fundamental conviction that God, as the highest being, existed, lived and revealed himself truly, and thus, God is absolutely knowable in essence, though not comprehensively. Even, man of that age "could be

\footnotetext{
18 Herman Bavinck, Reformed Dogmatics, vol. 2, God and Creation (Grand Rapids: Baker Academic, 2004), 29.

19 Calvin, Institutes I.5.9.

20 Calvin, Institutes I.13.1.

21 Van der kooi, As in a Mirror, 48.

22 Ibid., 236.
} 
more certain of that highest being than they were of themselves." ${ }^{23}$ It is under this pre-modern context that Calvin develops his doctrine of union with Christ.

\section{Barth}

While, we need to keep in mind that Barth, in contrast to Calvin, is a modern theologian in the twentieth-century context with his twentiethcentury concerns. In Barth's age, the theological landscape, comparing with that of Calvin, had been greatly reshaped by the Enlightenment, which reached its climax at the time of Immanuel Kant (1724-1804) with a new epistemological presupposition. It is a general consensus among theologians that "Kant de facto marks a watershed in western theology." 24 After the impact of Enlightenment, there is no way to resurrect again the older pre-modern belief system. Theologians must response the challenges posted by Kant's new epistemology, from which the modern theology was born.

Undoubtedly, Barth is an heir of the modern tradition. Although Barth gained his reputation for his anti-liberalism theology since his bombshell commentary on the Epistle to Romans in 1919, Barth, at the end of his life, self-reflects that "I am a child of the nineteenth century." 25 Bruce McCormack also argues that Barth's theology is "demonstrably modern in character" 26 , which is well summarized as following:

Beyond the historicizing tendencies unleashed by the rise of historical consciousness, any truly "modern" theology will also include the following: (1) an acceptance, in principle at the very least, of critical methods for studying the Bible; (2) a recognition of the loss of respect among philosophers for classical metaphysics in all of their (Greek) forms; (3) the recognition of the breakdown of the old Aristotelian-biblical cosmology in the course of the seventeenth century; (4) and acceptance of the necessity of constructing doctrine of creation and providence which

\footnotetext{
Ibid., 241.

Van der Kooi, As in a Mirror, 225.

Quoted from The Cambridge Companion to Karl Barth, 11.

Bruce L. McCormack, Orthodox and Modern: Studies in the Theology of Karl Barth (Grand Rapids: Baker Academic, 2008), 10.
} 
find their ground in more modern theological and/or philosophical resources. ${ }^{27}$

As McCormack discloses, modern theology fully embraces Kant's philosophical presupposition, though not all of the four criteria above are the direct results of Kant's new epistemology. In another place, the leading Barth scholar, McCormack further points out:

All of his (Barth) efforts in theology may be considered, from one point of view, as an attempt to overcome Kant by means of Kant; not retreating behind him and seeking to go around him, but going through him. ${ }^{28}$

As a post-Kantian (i.e. modern theologian), Barth, in line with his predecessors, attempts to "overcome Kant by means of Kant." The "overcome Kant" here should better be understood in an indirect way, because Barth's theology is not a direct response to Kant, but primarily to those liberal theologians influenced by Kant.

According to McCormack, Barth reconstructs Christian orthodoxy "with the help of Kant's epistemology and (later) Hegelian ontology" to "overcome Kant." 29 Fully embracing the Kantian epistemology, Barth negates the traditional theology proper since Medieval scholasticism, which directly talks about the being or essence of God and makes God's being prior to, or higher than, God's act. The traditional orthodox methodology to know God and then His work, for Barth, also will inevitably lead to natural theology or human religion, which just falls prey to Ludwig Feuerbach's critic of Christianity. The solution Barth adopts, therefore, is neither Kantian's turn to moral sphere, nor Schleiermacher's appealing to human feeling, but Christocentric actualistic ontology, which is also the core of Barth's attempt to "overcome Kant."

\footnotetext{
27 Ibid., 11; numbers added.

28 Bruce L. McCormack, Karl Barth's Critically Realistic Dialectical Theology: Its Genesis and Development, 1909-1936 (New York: Oxford University Press, 1995), 465-66.

29 McCormack, Orthodox and Modern, 17. McCormack also points out Barth's difference with Hegel, see page 190-191. My understanding of Barth's philosophical presupposition chiefly relies on the leading Barthian scholar's interpretation.
} 
Barth reversely starts with the act or the work of God, which is demonstrated by the existing reality of Christian Church, in our knowing of the intuitable God. Namely, only when we encounter God himself in His act or work, can our talking about God's being or essence be possible and meaningful. Or, in Barth's words, "God's being consists in God's act," 30 or "God's being is...the event of God's act." 31 Therefore, "the whole being and life of God is an activity, both in eternity and in worldly time." 32 The particular act of God towards human being, according to Barth, is God's self-revelation in the history of Jesus Christ, which is determined by God's act of election in eternity. "God acts as Jesus acts," thus, it is "only in Jesus Christ and not elsewhere" can we know the eternal God. ${ }^{33}$ In this way, Barth actualizes the revelation of God in Jesus Christ. Revelation, for Barth, is not static but a dynamic event. In this event of revelation, says Barth, "God, the Revealer, is identical with His act in revelation and also identical with its effect." 34

This Christocentric actualism has drawn attention of Barth scholars for a long time. According to George Hunsinger, actualism "is the most distinctive and perhaps most difficult" motif in understanding Barth's theology, which is so pervasive that "Barth's whole theology might well be described as a theology of active relations." 35 Barth's actualism has both epistemological and ontological significance. Opposing essential ontology, actualistic ontology means, in a simplified way, that "its act is its being, its status is its dynamic, its essence is its existence." 36 This Christocentric actualism is clearly revealed in Barth's construal of his Trinity theology, in which Barth believes that "the economic activity of God ought to control reflection on God's immanent, Trinitarian

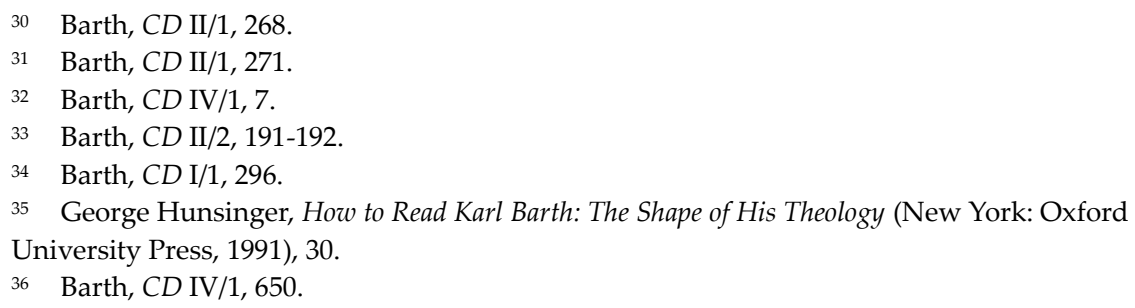


relationships." 37 The application of actualism in Christology is the most startling one in Barth's theology, which inevitably influences Barth's doctrine of union with Christ.

\section{On The Root of Union with Christ}

Calvin

It is important to note that, since his 1539 Institutes, Calvin has placed his doctrine of predestination and election in his soteriology discussion, which implies that his chief concern is soteriological issues. ${ }^{38}$ Hence, it should not be surprised that Calvin spends four chapters on eternal election (III.xxi-xxiv) in book III of his 1559 Institutes. Though being treated at the end of book III, divine election for Calvin actually has a foundational role in "The Way in Which We Receive the Grace of Christ," which is our union with Christ. As Calvin explicitly declares that the eternal election is "the foundation and first cause, both of our calling and of all the benefits which we receive from God." 39

\section{Election as Grace}

As the origin of faith which unites us to Christ, eternal election, for Calvin, must firstly be understood as the sovereign "free mercy" or "grace" from God. Consistently rejecting all forms of synergism through Book III of his 1559 Institutes, Calvin introduces the concept of election after his teaching of sanctification and justification:

We shall never be clearly persuaded...that our salvation flows from the wellspring of God's free mercy until we come to know his eternal election, which illumines God's grace by this contrast: that he does not indiscriminately adopt all into the hope of salvation but gives to some what he denies to others. ${ }^{40}$

\footnotetext{
37 Richard E. Burnett, ed., The Westminster Handbook to Karl Barth, The Westminster Handbooks to Christian Theology (Louisville: Westminster John Knox Press, 2013), 32.

38 Muller, The Unaccommodated Calvin, 183.

39 John Calvin, Commentaries on the Epistles of Paul to the Galatians and Ephesians, Eph. 1:4. Translated and edited by William Pringle. Grand Rapids: Christian Classics Ethereal Library. Accessed December 6, 2016. http://www.ccel.org/ccel/calvin/calcom41.iv.ii.i.html.

40 Calvin, Institutes III.21.1.
} 
Since God does not all adopt all people indiscriminately, only a limited number of people are eternally elected to be given "the hope of salvation," while the rest are predestined to destruction. "Election would be inconsistent," Calvin writes, "if it were not placed in opposition to reprobation." 41 This stark contrast highlights that election is a gracious gift from God. In making His eternal decree, God considers nothing outside himself, but His good pleasure. "If we ask why God takes pity on some, and why he lets go of the others and leaves them, there is no other answer but that it pleases him to do so." 42 So Calvin refutes the absurd notion that election is out of God's foreknowledge of human's merits, which will inevitably, to some extent, make human God's co-worker in salvation. We are elected to be holy, but not because we are already holy; this order should never be reversed. ${ }^{43}$ Just as God's mercy and grace being displayed in His eternal election, so does His just and righteousness in His condemnation, for God is debtor to no one. Thus, Calvin boldly argues for a double predestination in his 1559 Institutes, in which both election and reprobation are viewed as the active act of God. ${ }^{44}$ Given that reality, election, for Calvin, is indeed grace in nature.

\section{Christ and Election}

Then what is the relationship between God's eternal election and Christ? Isn't it that the decree of election must exclude any need of redemption by Christ? Absolutely not. In light of the two natures of Christ, Calvin understands Jesus Christ as both the Author and Mediator of God's decree.

\footnotetext{
41 Calvin, Institutes III.23.1.

42 John Calvin, Sermon on Ephesians 1:3-4, quoted from François Wendel, Calvin: Origins and Development of His Religious Thought (Grand Rapids: Baker Books, 1997, 1963), 273; cf., Institutes III.22.1.

43 Calvin, Institutes III.22.3.

44 Calvin, Institutes III.23.8. Though frequently being accused for his "terrible" doctrine of double predestination, Calvin should never be considered as the originator of this doctrine, which, as a matter of fact, is a catholic doctrine since Augustine and taught throughout the church history. For Calvin himself, this doctrine of predestination and election primarily functions as giving assurance of salvation to believers, which is supposed to be a comforting message for the church in persecution.
} 
Calvin refers to Christ as the author of election both in his commentary and Institutes. In his commentary on John 13:18, I am not speaking of all of you; I know whom I have chosen, Calvin states:

Christ gives here a clear proof of his Divinity; first, when he declares that he does not judge after the manner of men; and, secondly, when he pronounces himself to be the Author of election. For when he says, I know, the knowledge, of which he speaks, belongs peculiarly to God; but the second proof - contained in the words, whom I have chosen - is far more powerful, for he testifies that they who were elected before the creation of the world were elected by himself. ${ }^{45}$

Here Jesus Christ, Calvin argues, clearly reveals His deity by referring Himself as the Author of the eternal election. Christ plays an active role in the eternal salvific election according to his divine nature, because, in Calvin's mind, "the Word abides everlastingly one and the same with God, and is God himself." 46 Later on when commenting on John 15:16, You have not chosen me, but I have chosen you, Calvin discusses both temporal ordination and eternal election. ${ }^{47}$ Again, "Christ declares himself to be the Author of both," says Calvin, "since it is only by him that God acts, and he acts along with the Father." ${ }^{48}$ So the authorial role of Christ is reflected in that, He, the elector, also acts along with the Father.

When it comes to his Institutes, Calvin, in most cases, ascribes election only to God the Father, but it is his premise that the Son must participate in the decree of election as one person of the Triune God. He writes:

Meanwhile, although Christ interposes himself as Mediator, he claims for himself, in common with the Father, the right to choose...From this we may

\footnotetext{
45 My study in this section heavily relies on Gibson, Reading the Decree, Chapter 2. John Calvin, Commentary on the Gospel According to John, John 13:18. Grand Rapids: Christian Classics Ethereal Library. Accessed December 6, 2016. http://www.ccel.org/ccel/calvin/calcom35.iii.iv.html.

46 Calvin, Institutes I.13.7

47 John Calvin, Commentary on the Gospel According to John, John 15:16. Accessed December 6, 2016. http://www.ccel.org/ccel/calvin/calcom35.v.iv.html.

48 Ibid.
} 
infer that none excel by their own effort or diligence, seeing that Christ makes himself the author of election. ${ }^{49}$

Clearly, this authorial role is performed by Christ as the second person of the Trinity. As the eternal Son of God, Christ decrees to save some and condemn some along with the Father and the Spirit. For the same reason, Calvin also speaks of the church as elected by Christ, the one who "has chosen and set apart the church as his bride." 50 To conclude, there are indeed clear and direct references to Christ as the Author of election in Calvin's works.

It is worth noting that Calvin, in this same passage, also explicitly refers to Christ as the author of our union with Christ, "Christ does not allow any of those whom he has once for all engrafted into his body to perish (John 10:28);" "51 Here the term "engraft into Christ" is one of Calvin's typical expressions of our union with Christ. So, what Calvin suggests here is that Christ has united believers with Himself "once for all." What does that mean? In line with the context of this passage, we can conclude that Calvin is suggesting an objective union of believers with Christ in their election in eternity, in which Christ in his divine nature is the Author of election, and also of this objective union. Thus, Calvin does not only have an objective union with Christ in mind, but also consider Christ as the author of this objective union. This objective aspect of union with Christ of Calvin will be examined in detail later on.

Besides His authorial role, Jesus Christ also performs a mediatorial role, in which Jesus Christ stands alongside the believers as the object of God's election and also executes the divine decree of election. Christ is appointed to be Mediator to obtain salvation for us solely out of God's own good pleasure.52 Thus, Calvin insists that our election "is to be understood and recognized in Christ alone." 53

\footnotetext{
Calvin, Institutes III.22.7.

Calvin, Institutes III.22.7, IV.1.10.

Calvin, Institutes III.22.7, emphasis added.

Calvin, Institutes II.17.1.

Calvin, Institutes III.24.5.
} 
In what way then does Christ mediate our eternal election? The passage Ephesians 1:4, which tell us that our election is "in Christ" and "before the foundation of the world," is crucial to Calvin's understanding of Christ's mediatorial role to the eternal decree. When commenting this verse in his Institutes, Calvin writes

When Paul teaches that we were chosen in Christ "before the creation of the world" (Ephesians 1:4a), he takes away all consideration of real worth on our part, for it is just as if he said: since among all the offspring of Adam, the Heavenly Father found nothing worthy of his election, he turned his eyes upon his Anointed, to choose from that body as members those whom he was to take into the fellowship of life. Let this reasoning, then, prevail among believers: we were adopted in Christ into the eternal inheritance because in ourselves we were not capable of such great

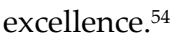

The reason that we must be elected "in Christ," with Christ as the Mediator of our election, is "because in ourselves we were not capable of such great excellence." In his sermon on Ephesians, Calvin further explicates:

Did God, then, have an eye to us when he vouchsafed to love us? No! No! For then he would have utterly abhorred us. It is true that in regarding our miseries he had pity and compassion on us to relieve us, but that was because he had already loved us in our Lord Jesus Christ. God, then, must have had before him his pattern and mirror (patron et miroir) in which to see us, that is to say, he must have first looked on our Lord Jesus Christ before he could choose and call us. ${ }^{55}$

Here Calvin refers to Christ as a mirror in which God looks to see us. Though God has willed a group of people from eternity to be His own, they are too low to be worthy of God's election. Instead of looking at us, God turns His eyes upon Christ and elects Him instead. Our election only comes secondary when God regards us as bodies of Christ or members in Christ. Namely, our election is not from the sight of our deserving, but

\footnotetext{
54 Calvin, Institutes III.22.1.

55 John Calvin, Sermons on the Epistle to the Ephesians (Edinburgh: Banner of Truth, 1973),

26. Quoted from Gibson, Reading the Decree, 66.
} 
because we are in Christ. Christ, hence, in Calvin's metaphors, is "a book, a guardian, a mirror, a seal and a pledge" of our eternal election. ${ }^{56}$ Our eternal election in Christ could be described as a representative election, in which Christ is the representative of our election as the Head of the Church. ${ }^{57}$

How, then, could we come to be in Christ before our election? Or put it another way, how does Calvin understand this pre-temporal "in Christ" and our election logically? It is here that Calvin's obscured expression of objective union with Christ is revealed again. Let us look at Calvin's comments on Ephesian 1:4 again:

For if we are chosen in Christ, it is outside ourselves. It is not from the sight of our deserving, but because our heavenly Father has engrafted us, through the blessing of adoption, into the body of Christ. ${ }^{58}$

In this 1548 Commentary on Ephesians, Calvin already illustrates that the reason of our being chosen in Christ is that "because our heavenly Father has engrafted us... into the body of Christ." That is a very clear "union with Christ" language, but it could not be Calvin's prevalent temporal union with Christ. Though Calvin does insist that our union with Christ in time is "a sufficient clear and firm testimony" of our eternal election, 59 there is no way a temporal event could be the reason of a pre-temporal action. Thus, what Calvin means here is the objective union with Christ before time when God the Father handed over a people to the Son. This point is made clearer in Calvin's 1559 Institutes.

Accordingly, those whom God has adopted as his sons are said to have been chosen not in themselves but in his Christ (Ephesians 1:4); for unless he could love them in him (Christ), he could not honor them with the inheritance of his kingdom if they had not previously become partakers of

\footnotetext{
$56 \quad$ Ibid., 58.

57 Gibson, Reading the Decree, 64.

58 John Calvin, Commentary, Eph. 1:4. Accessed December 6, 2016.

http://www.ccel.org/ccel/calvin/calcom41.iv.ii.i.html.

59 Calvin, Institutes III.24.5.
} 
$\operatorname{him}\left(\right.$ Christ) ${ }^{60}$

Still when commenting Ephesians 1:4, Calvin argues that if we "had not previously become partakers of him (Christ)," or being "in Christ," God cannot love us and honor us with the inheritance of his kingdom. Apparently, this previous partaking of Christ is the pre-temporal objective union with Christ. Calvin goes on to comment that:

Christ, then, is the mirror wherein we must, and without self-deception may, contemplate our own election. For since it is into his body the Father has destined those to be engrafted whom he has willed from eternity to be his own, that he may hold as sons all whom he acknowledges to be among his members, we have a sufficiently clear and firm testimony that we have been inscribed in the book of life (cf. Revelation 21:27) if we are in communion with Christ. ${ }^{61}$

It should be clear now that, for Calvin, God's will to save some to be His own comes first in the logical order. While, his decree to make them engrafted into the body of Christ and save them through their union with Christ, which is the establishing of the objective union with Christ, comes second. ${ }^{62}$ Both of them, for Calvin, taken together as a unity, constitutes the election. Based on that, our communion with Christ by Spirit worked faith in time, which is the realization of the objective union with Christ, is considered by Calvin as the proof or witness of our eternal election. To conclude, though the exact term of "objective union with Christ" is never adopted by Calvin when addressing his doctrine of election, this idea runs through his explanations and metaphors.

So far, we have observed that Christ, for Calvin, is both the Author and the Mediator of our election. To conclude, God the Father does not only decree the beginning and the end of our salvation in election, but

\footnotetext{
60 Calvin, Institutes III.24.5.

61 Calvin, Institutes III.24.5.

62 See Jonathan Herbold Rainbow, Princeton Theological Monograph Series, vol. 22, The Will of God and the Cross: a Historical and Theological Study of John Calvin's Doctrine of Limited Redemption (Allison Park: Pickwick Publications, 1990), 78. Cf, "Although we are elected in Christ, still in terms of order God's considering us as among his own people is first, and his making us members of Christ is second." John Calvin, CO 9:714.
} 
also the means. Our election in Christ determines that our whole salvation is also in Christ by grace.

Barth

Now, let us turn to see how does Barth view election as the root of our union of Christ. It is widely recognized that the doctrine of election holds a primary place in the architecture of Barth's thought. As the primal decision of God, election is "the very center of the divine self-revelation," from which all divine activities are issued and grounded. ${ }^{63}$

1. Election as the Gracious Covenant God's Self-determination

In line with his Christocentric actualism, this act of election, the primal decision of God, for Barth, explains not merely what God does, but more importantly who God is. As Barth says, the topic of election "is part of the doctrine of God because originally God's election of man is a predestination not merely of man but of Himself." 64 Unlike Calvin's treatment, therefore, Barth locates his teaching of election in the second part of The Doctrine of God (Church Dogmatics Vol. II/2), and his focus is the gracious God revealed in election, rather than the soteriological implications of God's gracious election.

According to Barth, it is God's eternal gracious free will not to be God alone, but to be "God for us" by entering into a covenant relationship with humans. ${ }^{65}$ Once God has willed to enter into this irrevocable covenant relationship, Barth says, "He could not be God without it." 66 This self-binding or self-giving of God to human who has not merited it is the free decree of God, which is also what Barth calls "the divine election of grace," the wholly gracious, wholly free primal decision of God.67 What happens simultaneously in this divine election of grace is God's institution of the eternal covenant of grace, in which

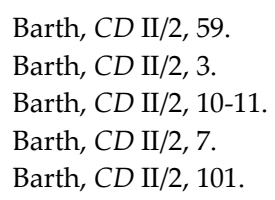


God decides Himself for grace by constituting Himself "the Lord of the covenant." 68 All the promise and blessings of God that follows in time are grounded in His self-determination to be the gracious covenant God, which Barth testifies:

All the joy and the benefit of his work as Creator, Reconciler and Redeemer, all the blessings which are divine and therefore real blessings, all the promise of the gospel which has been declared: all these are grounded and determined in the fact that God is the God of the eternal election of His grace. ${ }^{69}$

The eternal election of grace is placed at the head of all other Christian dogmas: creation, reconciliation and redemption. Therefore, the doctrine of election, in Barth's words, specifically functions as "the basic witness" to the gracious covenant God who loves in freedom..$^{70}$

To know who God is and what election is, Barth says, "we must look only upon and to the name of Jesus Christ, and the existence and history of the people of God enclosed within Him." 71 What does that mean? Barth explains:

In the person of His Eternal Son, He (God) has united Himself with the man Jesus of Nazareth, and in Him and through Him with this people... In this determination, as carried through by His own decision, God is, therefore, the subject of everything that is to be received and proclaimed in the Christian Church. All His work takes place according to this plan and under this sign. ${ }^{72}$

Note what Barth talks about here is God's eternal determination of the incarnation of God's eternal Son. In that eternal decision, God, in the person of His eternal son, has somehow united Himself with the man Jesus of Nazareth, and the people enclosed in Him. That means humanity, by way of anticipation, has been united with God through their pre-

\footnotetext{
Barth, $C D$ II/2, 5-9.

Barth, $C D$ II $/ 2,14$.

Barth, $C D$ II $/ 2,93$

Barth, $C D \mathrm{II} / 2,54$.

72 Barth, $C D \mathrm{II} / 2,8$.
} 
temporal union with or being enclosed in Christ. Thus, God's self-giving, to be in detail, is the giving up of His Son in His willing of incarnation. God's free love is demonstrated in the form of deepest condescension through the covenant realized in the election of Jesus Christ, the union of God with humans. In this sense, Jesus Christ is indeed "the election of God's grace directed towards man," and "the election of God's covenant with man."73

How exactly does Jesus Christ realize that grace of election and the eternal covenant? Identifying the divine predestination as the election of Jesus Christ, Barth asserts that Jesus Christ, the very God and very man, "is God's eternal, twofold predestination."74 As both the electing God and elected man, Jesus Christ on the cross reveals the twofold will of God that human is chosen for salvation, while God in Christ chooses himself for damnation. Thus, both election and rejection are predestined in Jesus Christ, the former is for man - election, salvation and life, and the latter is for God Himself-rejection, reprobation and death. ${ }^{75}$ In this way, Barth transformed the double-predestination from a division of the saved and the lost into a division between human and divine. In this double predestination, "man stands only to gain," while "God stands only to lose," because God could procure Himself nothing from man, but should give Himself to man by hazarding His Godhead and power and status. ${ }^{76}$ That is how the grace of God ultimately triumphs.

Therefore, Barth concludes:

The doctrine of election must be understood quite definitely and unequivocally as Gospel; that it is not something neutral on the yonder side of Yes and No; that it is not No but Yes; that it is not yes and No, but in its substance, in the origin and scope of its utterance, it is altogether Yes. ${ }^{77}$

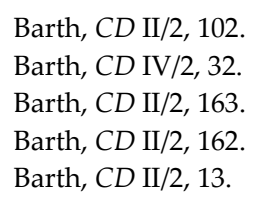


The first and last word of God towards human beings, according to Barth, is Yes and not No. That is God's primal determination within Himself of all His dealing with the not-yet existent universe. Therefore, this election of grace is not only "the sum of gospel," but "the whole of the Gospel, the Gospel in nuce," "the very essence of all good news."78 All God's ways and works begins with this free grace of election, Jesus Christ.

2. Jesus Christ and Election

Jesus Christ "is no less the original Subject of this electing than He is its original object." 79 According to Barth, neither Calvin nor his successors understands Christ to be the Subject of the eternal election. ${ }^{80}$ Barth questions that "if Jesus Christ, is not really the electing God, not the election itself, not our election, but only an elected means whereby the electing God... elected," then, "how can even the Word of God give us assurance?" 81 Even, "what shall we really know at all of a divine electing and our election?" 82 Barth claims that Calvin "did not even perceive this question," thus, "we have to bring against his (Calvin's) whole doctrine of predestination." 83

However, according to our previous study on Calvin, Barth apparently misses Calvin's commentaries on verses such as John 13:18 and 15:16, in which Calvin does refer to Christ, the eternal logos, as "the author" or the subject of the eternal election. So, is it really necessary that Barth is so critical of Calvin and even rejects Calvin's whole doctrine of predestination? Actually, we should not fault Barth too much for his radical departure. Barth's conception of Jesus Christ as the subject of election is so different in content from Calvin's that even he had been aware of Calvin's authorial Christ, he would not change much of his criticism on Calvin. ${ }^{84}$ The crucial difference is that when Calvin speaks of

\footnotetext{
Barth, CD II/2, 13-14.

Barth, CD II/2, 105.

Barth, CD II/2, 110-111.

Barth, CD II/2, 111.

Barth, CD II/2, 105.

Barth, CD II/2, 111.

84 Gibson, Reading the Decree, 41.
} 
Christ as the author of election, he is simply saying that the second person of the Trinity, with the triune God, makes the eternal divine decision of election and rejection, namely, his authorial Christ presupposes the pre-existence of God the Father's Son, the Logos asarkos (the Word without flesh); while Barth, in his proposal of Jesus Christ as the subject of election, has the pre-existence of the man Jesus of Nazareth, or more accurately, the God-man Jesus Christ in mind.

Based on his reading of John 1:1-2, Barth concludes that the eternal Logos has a name, and His name is Jesus. ${ }^{85}$ From all eternity God elects to bear this name, because "from and to all eternity God is the electing God." 86 In this way, Barth removes the distance between Logos asarkos and the God-man Jesus Christ. Accordingly, there is no other access to God apart from the person of Jesus Christ, who "is God's Word, God's decree and God's beginning," and more emphatically Barth says, "before Him and above Him and beside Him and apart from Him there is no election, no beginning, no decree, no Word of God." 87 Therefore, Barth is never tired of repeating that it is Jesus Christ, the whole God-Man in His divine-human unity, who is the subject of election, but not an absolute Logos asarkos. By identifying the eternal logos with Jesus Christ, Barth also crowds out the Calvinist notion of decretum absolutum. Barth says, "there is no such thing as a decretum absolutum," because "there is no such thing as a will of God apart from the will of Jesus Christ." 88 Calvin's decretum absolutum is, thus, replaced by Barth with his decretum concretum, the divine self-determination in the God-Man Jesus Christ. In this sense, there is no more hidden God and hidden decree of election. That is how Barth tried to avoid Calvin's "speculation" in theology.

The proper content of the divine election, according to Barth, is no one and nothing other than "the existence of this one created being, the man Jesus of Nazareth, and the work of this man in His life and death,

\footnotetext{
Barth, CD II/2, 98.

Barth, CD II/2, 77.

Barth, $C D \mathrm{II} / 2,95$.

Barth, $C D \mathrm{II} / 2,115$.
} 
His humiliation and exaltation, His obedience and merit." 89 Thus, unlike the tradition, Jesus Christ, for Barth, is not merely one of the elect, nor only the means or executor of the election of others, but He is himself the elect of God, the sole object of the eternal divine foreordination.

Jesus Christ "is the Son of God elected in His oneness with man, in fulfillment of God's covenant with man." 90 While our election is only derived from the election of the man Jesus. Following the tradition, Barth turns to Ephesians 1:4, "From the very beginning (from eternity itself), there are no other elect together with or apart from Him, but, as Ephesians 1:4 tells us, only elect "in" Him."91 Our election is only "in Him," in and with Jesus Christ's own election, which, according to Barth, "is universally meaningful and efficacious." 92 It is precisely in the election of Jesus Christ that we become secondary object of election, through which God elects covenant fellowship with all humanity. To be more specific, Jesus Christ's election "is the original and all-inclusive election," which "includes ours within itself and ours is grounded in His." 93 Thus, Jesus Christ "is the Lord and Head of all the elect, the revelation and reflection of their election, and the organ and instrument of all divine electing." 94

Barth goes on to work out three specific implications, which reveal his understanding of our election "in him" as an objective union with Christ or participation in Christ. First, our election, Barth understands, is "more grace, a participation in the grace of the one who elects, a participation in His creatureliness (which is already grace) and a participation in His sonship (which is eminently grace)..${ }^{95}$ Second, the election of the man Jesus is specifically His election to vicarious suffering unto death. Being elected "at the head and in the place of all others," the

\footnotetext{
89 Barth, CD II/2, 116.

Barth, CD II/2, 103.

Barth, CD II/2, 116.

Barth, CD II/2, 117.

Barth, CD II/2, 116-117, 120.

Barth, CD II/2, 116-117.

95 Barth, CD II/2, 121.
} 
man Jesus is ordained from all eternity to "take upon Himself the divine rejection of all others and to suffer that which they ought to have suffered."96 Because of Jesus's election of suffering, we, the secondary elects, are exempt from God's rejection. For this reason, our election should be understood only as grace in nature: "in the same Jesus God who is the Judge takes the place of the Judged, and they are fully acquitted, therefore, from sin and its guilt and penalty." 97 To be elected "in Him," thus, is to "be elected and made partakers of His grace." 98

Third, in the election of Jesus Christ, there is both the faithfulness of humans to God and God to humans, which is also the purpose and meaning of the eternal covenant willed by God. ${ }^{99}$ Grounded in his actualistic understanding, election, for Barth, is not a fixed and static predecision, but "a divine activity in the form of the history, encounter and decision between God and man," which is initiated by God in eternity. 100 This eternal activity of God demands its counterpart in man's response of electing God in return. Barth states unequivocally:

God elects man in order that man may be awakened and summoned to elect God, and to pray that he may give himself to Him, and that in this act of electing and prayer he may exist in freedom before God. ${ }^{101}$

God's election evokes and awakens faith, and for his part human meets and answers that faith, in which human accepts the self-giving of God, and thus, attests and activates himself as elected man. ${ }^{102}$ That, for Barth, is man's electing God in return. According to Barth, all those who are elected, thus, must cling to the fact that "it is actualised in Him (Jesus Christ) and on their behalf." The foreordained Jesus Christ has already made this response of a free election of God by human on behalf of all

\footnotetext{
Barth, CD II/2, 123-124.

Barth, CD II/2, 125.

Barth, $C D$ II/2, 123.

Barth, CD II/2, 126.

100 Barth, CD II/2, 175-176.

101 Barth, CD II/2, 180.

102 Barth, CD II/2, 177.
} 
those elected "in Him."

As it shows, Barth's construal of "in Him" suggests that all humanity are objects of the eternal divine election, connected in and to Christ, even before we come to exist. ${ }^{103}$ Barth clearly understands the relation of union expressed by the phrase "in Him" specifically as participation in Christ:

What can this election be...but...a participation in the grace of the One who elects, a participation in His creatureliness (which is already grace), and a participation in His sonship (which is eminently grace)? ${ }^{104}$

Our elect "in Him" means our objective participation in Christ from all eternity, in His grace, in His covenant, in His history, in His faithfulness. "'In Him' does not simply mean with Him... nor does it mean only through Him," Barth says, but means "in His person, in His will, in His own divine choice, in the basic decision of God which He fulfills over against every man." 105 Note here Barth's actualism: participation in Christ means participating in Jesus Christ' own divine choice, in the very basic decision of God. The basis of this objective participation in Christ, according to Barth, is "an ontological connection." In latter volumes, Barth explicates that there is "an ontological connection between the man Jesus on the one side and all other men on the other," because "an ontological declaration about their own being under His sovereignty" was made in the eternal election. ${ }^{106}$ That means mankind "objectively are His, they belong to Him, and they can be claimed as His de iure."107 Thus, Barth summarizes:

Not in and of himself, but in Jesus Christ as the eternal beginning of all God's ways and works, no man is rejected, but all are elected in Him to

\footnotetext{
103 Burnett, ed., The Westminster Handbook to Karl Barth, 61.

104 Barth, CD II/2, 121.

105 Barth, CD II/2, 116-117.

106 Barth, CD IV/2, 275.

107 Barth, CD IV/2, 275.
} 
their justification, their sanctification and also their vocation. ${ }^{108}$

Hence, in the self-determination of God, the eternal election of Jesus Christ, the eternal hypostatic union of the Son of God with the preexist man Jesus of Nazareth, all man's objective participatio Christi is established. This objective participatio Christi is further developed by Barth in the temporary reconciling history of Jesus Christ, which will be our focus next.

\section{Comparison}

Now I will bring together the previous work through a comparison. Firstly, let us look at the similarities in the two theologians' doctrine of election. As it is showed in last two chapters, both Calvin and Barth trace the root of union with Christ to the election of God in eternity. And both of them accurately understand election as the sovereign free grace of God in condescension, which precedes and includes the elects' response to God, rather than their response to God conditioning God's electing.

Moreover, both of the two theologians, to a certain extent, have a Christocentric doctrine of election. Following the Scripture, they similarly insist that Jesus Christ plays a central role for us to learn about our election. For Calvin, Jesus Christ is the "author," "mediator" and "executor" of the eternal election. As "the mirror" of our eternal election, Christ, on one hand, is the source and fountain of our election, while, on the other hand, $\mathrm{He}$ is also the revelation and certainty of it. ${ }^{109}$ Barth expresses the same thing when he asserts that Jesus Christ is both "the electing God and the elected man" in the eternal election. Therefore, the two theologians, though using different terms, both consider Christ as the Subject and Object of election. Besides, Barth also follows Calvin and the Reformed tradition to argue for God's double predestination, including both election and rejection. And both of them testify the biblical

\footnotetext{
108 Barth, CD IV/3, 482.

109 Calvin, Institutes, III.24.5.
} 
truth that God elects man only in and through Jesus Christ, who is foreordained in eternity to bear the rejection of God on the cross on behalf of the elects. So, the two theologians both suggest an eternal objective union between Christ and the people elected in Him, though it is only expressed implicitly in Calvin.

It is also their identical conviction that Jesus Christ has accomplished everything necessary for the elects' salvation, and contained within Himself everything that will be the elects' in a future redemption. For example, Calvin declares that in the death of Christ we have "the complete fulfillment of salvation," and also, we "have been born anew" through the resurrection of Christ.110 Hence, "the whole of our salvation is not to be sought anywhere else than in Christ." 111 That also tells us that Calvin has a similar forceful Christological emphasis like Barth, who is well known for his remarkable Christocentrism. When commenting on 2 Corinthians 1:19, for example, Calvin expresses his agreement with Paul that the "whole doctrine was summed up in a simple acquaintance with Christ alone, as in reality the whole of the gospel is included in it." 112 In other words, Christ "is the head-the sum - in fine, the consummation - of all spiritual doctrine," therefore, those "who teach anything else than Christ alone," Calvin says, "go beyond due limits." 113 So the two theologians share a similar Christological emphasis as well.

In spite of the above similarities, Barth could hardly be called the follower of Calvin on the doctrine of election. Although he retains Calvin's terms, such as double predestination, election as grace and reprobation, he dramatically re-orients the traditional Reformed understanding of the doctrine of election. In the preface, Barth frankly

\footnotetext{
110 Calvin, Institutes, II.14.13.

111 John Calvin, Commentary, John 3:16. Accessed December 6, 2016.

http://www.ccel.org/ccel/calvin/calcom34.ix.iii.html.

112 John Calvin, Commentary, 2 Corinthians 1:19. Accessed December 6, 2016.

http://www.ccel.org/ccel/calvin/calcom40.vii.iv.html.

113 Ibid.
} 
admits that while bringing much pleasure, his treating of election causes him "even greater anxiety," because:

The work has this peculiarity, that in it I have had to leave the framework of the theological tradition to a far greater extent than in the first part on the doctrine of God. I would have preferred to follow Calvin's doctrine of predestination much more closely, instead of departing from it so radically. ${ }^{114}$

Barth understood well that he has departed radically from Calvin in his doctrine of predestination and election.

As it shows previously, concerning the doctrine of election, Calvin's primary focus is that to whom does the election apply? While, Barth is more interested at the question that who is the God who elects? That is one of Immanuel Kant's influences on modern theology. Bruce McCormack accurately points out that "Barth's revolution is finally a revolution in the doctrine of God," which means "he is working with a very different divine ontology than did his forbears in the Reformed tradition."115 Therefore, it is my argument here that behind Calvin and Barth's different understanding of election, the root of union with Christ, actually is their distinct ontological presupposition.

We have noted that Barth and Calvin have a totally different understanding on the scope and content of election. Traditionally, there are two opposing viewpoints that dominate the debate regarding the doctrine of election: Calvin's and the Reformed Calvinistic unconditional, individual election with the limited atonement of Christ, and the Arminian conditional, individual election with the unlimited atonement of Christ. However, Barth proposed a third view, in which the sole election of God is the election of Jesus Christ, who, as both the electing God and elected man, alone bears both the election and reprobation from God. In Him, only in the person and works of Jesus Christ, there comes a derivative, unconditional, unlimited and corporate election of all

\footnotetext{
114 Barth, CD II/2, x.

115 McCormack, "Grace and Being" in The Cambridge Companion to Karl Barth, 93.
} 
humanity. Thus, Barth replaces Calvin's dreadful double predestination and limited election with a Christ-centered double predestination and universal election. But it should be clear now that Barth's concern is not so much on soteriology as ontology. ${ }^{116}$ His universal election of all humanity in Jesus Christ is only the most conspicuous difference with Calvin, the root of which lies at the much deeper level of epistemology and divine ontology. ${ }^{117}$

Behind Barth's revolutional understanding, in fact, is his departure from the classical essentialist ontology of Calvin and the Reformed tradition. In line with his Christological actualistic ontology, Barth identifies God's being with His act, God's being is a being-in-act, which is not in a general or abstract act, but in this particular eternal act of election in which God determines to be God-for-us in Jesus Christ. ${ }^{118}$ So the person of Jesus Christ, actualistically speaking, is Himself God's eternal act of self-determination and the history of its ongoing actualization. That means, for Barth, Jesus Christ is also Himself the history of covenant, the history of incarnation, and thus, the history of revelation and reconciliation. In this sense, there is no distance between the person and the works of Christ, and accordingly, there is no distance between the imminent trinity and the economic trinity. As Barth puts it:

We have consistently followed the rule, which we regard as basic, that statements about the divine modes of being antecedently in themselves cannot be different in content from those that are to be made about their reality in revelation...The reality of God in His revelation cannot be bracketed by an 'only', as though somewhere behind His revelation there stood another reality of God; the reality of God which encounters us in His revelation is His reality in all the depths of eternity. ${ }^{119}$

\footnotetext{
116 This point is also implied in Barth's ontological, rather than Calvin's soteriological, definition of decretum absolutum: "the notion that the true basis of election is an indeterminate and abstract good-pleasure of God." Barth, CD II/2, 115.

117 McCormack, "Grace and Being" in The Cambridge Companion to Karl Barth, 97.

118 Bruce L. McCormack, ed., Engaging the Doctrine of God: Contemporary Protestant Perspectives (Grand Rapids: Baker Academic, 2008), 215.

119 Barth, CD I/1, 479, quoted in McCormack, "Grace and Being" in The Cambridge

Companion to Karl Barth, 100. Emphasis added.
} 
The life history of Jesus Christ, thus, is the "essence" of the eternal Logos and the Trinitarian God "in all the depth of eternity," and God is this Jesus Christ. That is the actualistic ontology behind Barth's designation of Jesus Christ, the God-man, as the Subject of election.

While, presupposing the classical metaphysics and essentialist ontology, Calvin himself and the Reformed tradition commit to the socalled extra Calvinisticum. That term, according to Richard Muller, is used by the Lutherans to refer to the Reformed insistence that "the Word is fully united to but never totally contained within the human nature and, therefore, even in incarnation is to be conceived of as beyond or outside of (extra) the human nature."120 In other words, the incarnation, for Calvin and the Reformed tradition, does not exhaust the reality of the eternal divine Logos (Logos asarkos), because the finite is incapable of the infinite. Thus, Calvin maintains the conceptual distinction (logically, not temporally) between Logos asarkos (the Word without the flesh) and Logos ensarkos (the Word within the flesh) in the extra Calvinisticum. ${ }^{121}$ The divine Logos (the logos asarkos), who is logically prior to the eternal decision of election, should be differentiated from the Logos in the actual execution of the plan in time (Logos ensarkos), although they are inseparable. That also results to Calvin's differentiation of Christ's person and works, and furthermore, the economic trinity and imminent trinity. Just as Christ's works reflects the essence of the eternal Son perfectly but not exhaustively, so, for Calvin, the economic trinity reflects perfectly but not exhaustively of the imminent trinity.

\footnotetext{
120 Richard A. Muller, Dictionary of Latin and Greek Theological Terms: Drawn Principally from Protestant Scholastic Theology (Grand Rapids: Baker Book House, 1985), 111. As a matter of fact, "the so-called extra calvinisticum is not the invention of Calvinists," as Muller points out, "but is a christological concept, safeguarding both the transcendence of Christ's divinity and the integrity of Christ's humanity, known to and used by the fathers of the first five centuries, including Athanasius and Augustine."

121 Note Calvin did not use any of these terms in his works, but he does refer explicitly to the extra-Calvinisticum in essence. See Paul Helm, John Calvin's Ideas, new ed. (Oxford: Oxford University Press, 2006), 58-59.
} 
So far, it should be clear that the divergence between Calvin and Barth's doctrine of election is rooted in their distinct understanding of the divine ontology and God's revelation in their own context. Calvin's position, in Barth's thinking, "has led to fatal speculation about the being and work of the Logos asarkos," which ontologically bring about an unknown God.122 For Barth, that opens the door to natural theology or human religion, and makes Christianity inevitably fall prey to Ludwig Feuerbach's accusation, which is totally unacceptable for the post-Kantian Swiss theologian. ${ }^{123}$ Hence, Barth is motivated to depart from Calvin's whole doctrine of election, which, consequently, influence their doctrine of union with Christ.

\section{Evaluation}

Does Barth's actualistic identification of the economic Trinity and ontological Trinity successfully save Calvin and the Reformed tradition from the modern philosophers' accusations? Or, is the "correction" really necessary? It seems that Barth does not fully anticipate the potential problems of his innovation.

Along with Barth's anti-metaphysical speculation, Bruce McCormack further advances the logical implications of Barth's actualistic ontology in his article, Grace and Being, which becomes the focal point of debating among today's Barth scholars. In this article, McCormack asks what is the relationship, according to Barth's actualistic ontology, between election and Trinity? Then he points out, Barth's affirmation of Jesus Christ as "the second 'person' of the Trinity and the concomitant rejection of free-floating talk of the 'eternal Son' as a mythological abstraction," requires us to conclude that Barth, if being consistent, should see "the triunity of God, logically, as a function of divine election."124 Namely, the election of Jesus Christ, for Barth, should

\footnotetext{
122 Barth, CD IV/1, 181.

123 Barth, CD II/2, 64.

124 McCormack, "Grace and Being" in The Cambridge Companion to Karl Barth, 103.
} 
not just determine the identity of God, but should constitute God's being. "The decision for the covenant of grace is the ground of God's triunity and, therefore, of the eternal generation of the Son and of the eternal procession of the Holy Spirit from the Father and Son." 125 Therefore, not only the incarnation but the Trinity, for Barth, follows logically from the act of election, the primal decision of God. That is Barth's brilliant solution, in McCormack's mind, to close the door of metaphysical speculation. The weakness of this interpretation is that Barth himself nowhere says any such thing concerning the relation between election and trinity, which is noted by McCormack as well. It is McCormack's argument, since his doctoral dissertation, that Barth developed and shifted his doctrine of election after listening to a lecture by Pierre Maury in 1936, which was after Barth's completion of his doctrine of Trinity in CD I/1 and I/2.126 Barth's mature view of election, McCormack insists, demands a correction or retraction of his former doctrine of trinity, but Barth not only never did that, also never fully purged the essentialist ontology from his thought. ${ }^{127}$ Thus, it is the aim of McCormack to "register a critical correction against Barth," and remove the "inconsistency in Barth's thought." 128

George Hunsinger, McCormack's Princeton seminary colleague, criticizes McCormack's radical reading of Barth for being too consistent in following the logic of Barth's actualistic ontology. ${ }^{129}$ "Actualism," in Hunsinger's term, is only one of the motifs, which should not be the governing motif to interpret Barth's theology. In his recent book, Reading Barth with Charity, Hunsinger, characterizing McCormack and his followers as the "revisionist," titles himself the "traditionalist," who argues that Barth's doctrine of Trinity is the presupposition and ground

\footnotetext{
125 Ibid.

126 Ibid., 101; See also McCormack, Karl Barth's Critically Realistic Dialectical Theology, 456-63, for further detailed study.

127 McCormack, "Grace and Being" in The Cambridge Companion to Karl Barth, 102.

128 Ibid.

129 George Hunsinger, Reading Barth with Charity: A Hermeneutical Proposal (Grand Rapids: Baker Academic, 2015), 9.
} 
of God's pre-temporal decision of election. ${ }^{130}$ Thus, he vigorously defends Barth in a more traditional way. Following Barth, Hunsinger agrees with McCormack that the immanent trinity and economic trinity, the Logos asarkos and Logos ensarkos, are identified in content. ${ }^{131}$ However, according to Hunsinger, Barth never rejects the idea of the logos asarkos completely, and continues to affirm the extra-Calvinisticum. ${ }^{132}$ Thus, Hunsinger rails against McCormack's collapse of the immanent into the economic Trinity, and challenges him by asking "who or what this 'beingless' God is prior to election and the Trinity"? ${ }^{133}$ Hunsinger advocates a "doctrine of divine antecedence" to understand Barth's actualism, which basically asserts that all of God's ad extra acts find their "antecedent ground" in God's Trinitarian being ad intra. ${ }^{134}$ From the beginning of his writing to the end of his life, Hunsinger argues, "Barth continues to see the relationship between the economic trinity and the immanent trinity as one of "correspondence.'"135

Discontented with the label "revisionist," McCormack argues that his reading "has been amply prepared for in the German literature by Eberhard Jungel and Wilfried Harle and it has been stated explicitly by Hans-Theodore Goebel and Thiess Gundlach. In the English-speaking world, it has been stated explicitly by Rowan Williams and Paul M. Collins." 136 If triunity, for Barth, was logically prior to election, McCormack questions, how could Barth avoid "positing a mode of existence in God above and prior to God's gracious election - the very thing he accused Calvin of having done?" 137 And furthermore, "How can he (or anyone else) know that God is triune in and for himself,

\footnotetext{
130 Ibid., xi.

131 Ibid., 16.

132 Ibid., 158.

133 Ibid., 7.

134 Ibid., 8.

135 Ibid., 18-19.

136 Bruce L. McCormack, "Election and the Trinity: Theses in Response to George

Hunsinger," Scottish Journal of Theology 63, no. 2 (2010): 204.

137 McCormack, "Grace and Being" in The Cambridge Companion to Karl Barth, 102.
} 
independent of his eternal will to be revealed?" 138 Therefore, it is Hunsinger who represents the newer interpretation of Barth. It is beyond the limitation of this paper to analyze the two eminent Barth scholars' antithetical interpretations in details. But it seems that Hunsinger wants to force Barth into the ecumenical tradition by taming Barth's actualistic ontology and its radical implications. McCormack's reading of Barth in his historical context is more convincing, because it acknowledges the inconsistencies and progressions in Barth's thoughts.

The Barth wars help us to see, at least, that Barth's solution is not as ideal as it claims. If we follow McCormack's interpretation, then it might lead to greater abstraction of a "beingless" God who decides to be triune via election. Namely, Barth remains committed to divine hiddenness in one sense. Or, even if we neglect Hunsinger's incoherence and follow his ecumenical traditional interpretation of Barth, then it is still unreasonable for Barth to fault Calvin's metaphysical speculation, since Barth's own proposal does not improve much than Calvin's.

However, Barth's concern to avoid an abstract God should not be neglected, especially when we take his post-Kantian context into consideration. Given the dominant emphasis on human reason, morality and religious consciousness, Barth's actualistic ontology, as Michael Hortons observes, "undercuts the various attempts to offer mediations between Creator and creature other than Christ," the God-man Jesus Christ. ${ }^{139}$ Barth is also at his best to counter the prevalent "neo-Hegelian tendency to synthesize the Creator and the creature, Christ and his work" at that time. ${ }^{140}$ Nevertheless, adopting many modern presuppositions, Barth is not as successful as he aspires. In fact, Barth, removing the objective absolute authority of the Scripture and subjectivizing the revelation of God, ironically makes both God and election new speculations and abstractions. If we follow Barth's logic consistently, as

\footnotetext{
138 Ibid.

139 David Gibson and Daniel Strange, eds., Engaging with Barth: Contemporary Evangelical Critiques (New York: T \& T Clark, 2008), 352.

140 Ibid.
} 
McCormack interprets, then we will finally end up with conflating the creature into the Creator, since the "beingless" God, while making the primal decision of election, must presuppose the fallen man before becoming triune. ${ }^{141}$ Consequently, God's triunity will be contingent as creation and fall, which in fact denies the aseity of God. To conclude, Barth's actualistic ontology does not help him to escape a hidden God as he accuses Calvin, and Barth himself actually is a very speculative theologian at many points.

On the other hand, does Calvin's essentialist ontology necessarily lead to speculation and abstraction? It is true for Calvin and Reformed tradition that God is the pure being who is infinite and spiritual in essence. But this God is by no means distant or totally abstract for the pre-modern theologians. ${ }^{142}$ Calvin, in the same medieval theological context, also adapts the Aristotelian metaphysics to explicate the biblical concept that "God's being forms the basis of his acts ad extra, without surrendering his intimacy with creation." ${ }^{143}$ In His act ad extra, particularly in the reconciling work of Jesus Christ, God, for Calvin, truly reveals himself yet remains to be incomprehensible for our finite mind. In that sense, Calvin's extra-Calvinisticum construal of God is hidden to some degree. But does that necessarily mean Christ's incarnation "is merely a role he plays," and it "tells us nothing about who or what the logos is in and for himself" as McCormack claims? ${ }^{144}$ Definitely not! For Calvin, God the Father cannot be hidden behind Christ, the author of election:

Moreover, since he is the eternal wisdom of the Father, his unchangeable truth, his firm counsel, we ought not to be afraid of what he tells us in his Word varying in the slightest from that will of the Father which we seek. Rather, he faithfully reveals to us that will as it was from the beginning

\footnotetext{
141 James J. Cassidy, “Trinity and Election,” Westminster Theological Journal 71/1 (2009), 79.

142 Richard A. Müller, "The Barth Legacy: New Athanasius or Origin Redivivus? A Response to T.F.Torrance," The Thomist 54 (1990): 696; Quote from Cassidy, Trinity and Election, 80 .

143 Ibid.

144 McCormack, "Grace and Being" in The Cambridge Companion to Karl Barth, 97.
} 
and ever shall be. ${ }^{145}$

Instead, the incarnate Christ, as autotheos and the eternal wisdom of the Father, is the perfect expression of the divine essence. Therefore, Calvin's classical essentialist ontology is far from abstract and speculative than Barth's actualistic ontology. Maybe rather than questioning Calvin, we should ask Barth isn't becoming the Trinity merely a role that the "beingless" God plays?146

\section{Conclusion}

It is my conclusion here that Calvin and Barth's understandings on the root of union with Christ, namely the eternal election, are very different, which is fully displayed in their contrasting ontological presuppositions. That difference inevitably results to Calvin and Barth's distinct characterizing of union with Christ, which will be studied in the second part of my paper.

145 Calvin, Institutes, III.24.5.

146 Ibid., 80. 
